\title{
Advices on Budget Models for Equality in High Schools: The Case of Turkey*
}

\begin{tabular}{ccc}
\hline Article Type & Received Date & Accepted Date \\
Research & 3.05 .2020 & 20.07 .2020 \\
\hline
\end{tabular}

\section{Ece Özdoğan Özbal**}

\section{Kasım Karakütük***}

\begin{abstract}
The schools' budgets and the management of budgets is important for the effective maintenance of schools. School budgets are an important tool for ensuring equality within and among schools. In this study which aims to assert a suggestion on budget management model providing equity and decreasing problems, detecting different income and expense relationships in the school's budgets, the associational status of incomes and expenses of 1180 high schools in Turkey has been examined and the views of 60 school members (school principal, teacher, student, parents, school parent association member) about the budget management model have been evaluated. In the study, it was determined that there was a significant relationship between high school budgets and school-parent association budget of the school and the intangible right, movable property, maintenance and repair expenses. While high school principals define the ideal budget model as a model in which the budget is provided by the state and they have a more effective role, other school members consider the budget must be comprised of the contributions of individuals and different institutions other than the state, and different school members also participate in the budget management process in addition to the school principal.
\end{abstract}

Keywords: School budget, school finance, budget management, management.

\footnotetext{
*This article is produced from the first author's doctoral dissertation. Ankara University Educational Sciences Institute, Department of Educational Economics and Planning and presented as an oral presentation in $3^{\text {rd }}$ International Congress on Social Sciences-Humanities and Education with the title of "A study on budget management models in schools" in Istanbul, 17-18 December, 2018.

** Corresponding Author: Dr, Ankara University, Faculty of Educational Sciences, Elementary Education Department, Ankara, Turkey. E-mail: eozdogan@ ankara.edu.tr, https://orcid.org/0000-0002-6876-183X

***Prof. Dr., Ankara University, Faculty of Educational Sciences, Education Administration Department, Ankara, Turkey. E-mail: karakut@education.ankara.edu.tr, https://orcid.org/0000-0003-3136-1979
} 
Liselerde Eşitliği Sağlayıcı Bütçe Modeli Önerileri: Türkiye Örneği *

\begin{tabular}{ccc}
\hline Makale Türü & Başvuru Tarihi & Kabul Tarihi \\
Araştırma & 3.05 .2020 & 20.07 .2020 \\
\hline
\end{tabular}

Ece Özdoğan Özbal**

\author{
Kasım Karakütük***
}

\begin{abstract}
$\ddot{O} z$
Okulların bütçeleri ve bütçelerinin yönetimi okulların etkin sürdürülmesi açısından önemlidir. Okul bütçeleri, okul içinde ve okullar arasında eşitliği sağlamada önemli bir araçtır. Okul bütçelerindeki farklı gelir ve gider ilişkilerinin belirlenerek, sorunları azaltıcı ve eşitliği sağlayıcı bütçe yönetim model önerisinin ortaya konulmasının amaçlandığı bu araştırmada Türkiye'deki 1180 lisenin gelir ve giderlerinin ilişkisel durumu incelenmiş, ayrıca 60 okul üyesinin (okul müdürü, öğretmen, öğrenci, veli, okul aile birliği üyesi) bütçe yönetim modeline ilişkin görüşleri değerlendirilmiştir. Araştırmada liselere devlet tarafindan sağlanan bütçe ve liselerdeki okul aile birliği bütçesi ile menkul mal, gayri maddi hak alım, bakım onarım giderleri ve hizmet alımları arasında anlamlı bir ilişki olduğu belirlenmiştir. Lise müdürleri, ideal bütçe modelini devlet tarafından bütçenin sağlandığı ve kendilerinin daha etkin role sahip olduğu bir model olarak tanımlarken, diğer okul üyeleri devletin sağladığı bütçenin yanı sıra bireylerin ve farklı kurumların katkıları ile bütçenin oluşturulması ve okul müdürü dışında faklı okul üye temsilcilerinin de bütçe yönetim sürecine katılması görüşündedirler.
\end{abstract}

Anahtar Sözcükler: Okul bütçesi, okul finansmanı, bütçe yönetimi, yönetim.

\footnotetext{
*Bu makale, sorumlu yazarın Ankara Üniversitesi Eğitim Bilimleri Enstitüsü Eğitim Ekonomisi ve Planlaması Doktora Programı'nda Prof. Dr. Kasım Karakütük danışmanlığında tamamladığı doktora tezinden üretilmiştir ve 17-18 Aralık 2018 tarihlerinde İstanbul'da gerçekleştirilen 3. Uluslararası Sosyal Beşeri ve Eğitim Bilimleri Kongresi kongresinde "A study on budget management models in schools" başlığıyla sözlü bildiri olarak sunulmuştur.

** Sorumlu Yazar: Dr., Ankara Universitesi, Eğitim Bilimleri Fakültesi, Temel Eğitim Bölümü, Sınıf Eğitimi Anabilim Dalı, Ankara, Türkiye. E-posta: eozdogan@ ankara.edu.tr, https://orcid.org/0000-0002-6876-183X

*** Prof. Dr., Ankara Üniversitesi, Eğitim Bilimleri Fakültesi, Eğitim Bilimleri Bölümü, Eğitim Yönetimi Anabilim Dalı, Ankara, Türkiye. E-posta: karakut@education.ankara.edu.tr, https://orcid.org/0000-0003-3136-1979
} 


\section{Introduction}

Resource, environment and teaching staff are key points for the continuity of education. Budget must be provided to the education services, in order to meet the resources, The education sector is quite large and generating additional income for schools has been a difficult topic for policy makers for years (Guthrie, 1997). The failure to allocate sufficient budget and the lack of educational opportunities raise concerns due to its impact on the quality and maintenance of the education service.

The formation of the budget allocated for education by the state or private sector, the way education expenses are made are directly related to the educational policies of the countries. The budgets of the schools are established in line with the policies applied and the responsibilities of the institutions or persons concerned with the use of the budget are determined. In some countries, the distribution of the education budget is carried out centrally, while in others the planning and management of budget are made at local level or school-based budgeting. When evaluated globally, schools are often controlled and run by governments. In particular, government policies directly affect the ongoing educational and administrative processes in schools. As the distribution process of the allocated budgets and the management process are shaped in line with the resources forming the budget, government funds shape the management process. The state funds are mainly distributed through three mechanisms, in most cases: the level of basic funding, categorical financing, and the balancing of local tax revenues by the state (Terman and Behrman, 1997). In the local and school- centered approaches, providing, separation and use processes of the budget continue based on the school. In this approach, it can be said that the school principals has a more effective role. School- centered management approaches are called different names in the literature. Self managing schools, locally-autonomous schools, local management of schools, restructured schools, shared decision-making and devolution are some of these names (Davies and Hentschke, 1994). Budget management is important both in the state-dominated budget system and in the school-based budget system.

The determination of the budget allocated to schools and the budget management process directly related with the elimination of inequalities among schools or the deepening of inequalities. For this reason, the distribution of the budget to be allocated to schools has great importance. In order to minimize inequality among schools, considering the general tendency of the countries, three basic equalization approaches have been identified in various countries: the equalization of tax base to support education (e.g. in the United Kingdom, Australia and West Germany), equalization of expense per student or per capita (e.g. in USA and Canada) and equalization of physical inputs, mainly teaching service (e.g. in the Netherlands, Sweden and Norway) (Hough, 1993). However, these practices are not sufficient to ensure equity since the school institution is a multivariate and living institution, and there are the differences of the variables that make up the budget (the socio- economic situation of the families, the support of the local governments, the registration fees of schools, etc.).

It is emphasized that the point needed a solution in school budget is the "adequacy". However, the question of how "adequate" the education is, or how to transform educational measures into a financial formula is not explicitly mentioned (Augenblisck et al., 1997). Some studies (Odden et al., 2007) mention some methods (cost function, professional judgment, successful schools / regions and evidence- based) for the adequacy of financing. Among these, successful school / region and costfunction approaches provide estimates of sufficient expenses based on student level (and regulations for various student requirements), while professional judgment and evidence-based approaches suggest that the proposals are met with sufficient resources; and also focus on management, maintenance and transport functions as well as a series of program and strategies in primary, secondary schools and high schools (Odden et al., 2007). Although the aim of the methods used is to make the fair distribution of the budget come true, inequalities in schools have been reproduced in many parts ofthe world. In addition to the budget provided by the state in schools, the effort to create different additional budgets is noteworthy. This effort is related to the desire to provide more qualified education with increasing budget. While education expenditures per student vary, it is a fact that educational expenditures vary from region to region, and there may even be gaps between schools in close proximity in terms of school budgets. However, all of the state constitutions emphasize that education should be maintained sufficiently and equally, especially in public schools. In this way, the educational services can be given 
through school finance mechanisms / budgets designed to increase equity, competence and efficiency (Howell and Miller, 1997).

Competence related to the establishment of the school budget and the allocation of budget to schools has a public value adopted by the society. However, the budget inequalities of the wealthy and poor school districts show the contrast in practice. Inadequate budgeting and changing policies for schools deepen the gap between school budgets, especially under the influence of globalization. Even though school districts earn income from local funding sources, the state as well as federal aid and funding are insufficient to increase the capacity of students to meet their needs (Ikpa, 2016). The increase in the number of students in the school because of the increase in the population, the expectations from the education system, and the increased public expectations for the outputs cause direct additions to the schools' budget. While the requirements of the school are increased in both quantitative and qualitative terms, there is no increase in the budget of the school. While there are efforts to create a budget balance for schools having additional support (family, local government, etc.), it is observed that the schools that do not take this support due to low socio-economic environment have difficulties in their budgets.

Kozol's study (2005), contains a suffix to illustrate the inequality levels of resource allocation in the principal areas of the United States and the socio- economic distinction among school districts in these areas. As a result of the research, the financing / budget of school districts with very high level of child poverty is relatively low. This situation demonstrates that the socio-economic status of the environment in the school is its related to the school's budget, and supports the view that the differences in the socio-economic environment in which the school is located constitute the inequalities in the school budget. Välijärvi and Malin (2000) explain the socio-economic differences of the school for two reasons. The first one is the geographical location of the school, and the second is the selection of schools. The geographic location of the school determines where the students come from; therefore, students represent the social structure of that environment. Another point is that the school's choice of student or the student's choice of school cause the differences depending on the social status among schools. Socio-economic differences in the school budget are largely influenced by the contribution of families to schools. Adequate and well-educated parents contribute to schools where their children are educated and also contribute to the schools by collecting money through school-parent associations and by private donations (Brighouse, 2007). In regions with low levels of education and low income levels, the family is not expected to contribute to the school budget or the level of contribution is low. In support of these findings, Card and Payne (2002) reported that in the 1980s in the states where the school financial system was reported to be against the constitution, the resources of low-income regions increased, the increase in state aid to the poorer regions increased the expenditure in these regions, thus they concluded that the difference in expenses of poor and rich regions decreased. It was observed that the budgetary deficiencies of the schools also had a share in the common exams held as a result of the research, and therefore egalitarian systems to be provided in schools' budgets also had an effect on student education processes.

In any case, after a school has a budget, the important point is how to use the budget and how to distribute the expenses such as goods and services. To address this problem, school financing of the 1990s should go beyond financial inequalities and identify links between student achievement, educational progress and education financing (Odden, 1992). It is important that school budgets have budget management models that minimize inequalities among schools. It is more important to take into account the dynamics of the school as countries have different ways to create school budgets, and there are many reasons for differentiation, from cultural factors to countries' governance. In particular, education's meaning for countries and their expectations from education outline the budget and budget management processes in schools.

Considering this case in Turkey, schools are run in two ways as state and private and the financing of schools is mainly provided by the Ministry of National Education. In terms of education budget, the budgets for preschool education, primary and secondary education is considered as general budget; higher education budgets, as special budget. In the source provided to schools by the Ministry of National Education from the central budget, primary and secondary schools do not have a direct budget (primary school and secondary schools are not given a cash budget), while high schools are paid directly 
from the budget. The budget allocated to public high schools in Turkey, in particular, does not cover teachers' salaries. All processes related to teacher employment and payment of teacher salaries are carried out centrally by the Ministry of National Education. The budget allocated directly to state high schools is spent for the cost of goods, service expenses, maintenance and repair expenses, current transfers, capital expenditures and other expenses. Apart from the budget allocated by the state, high schools have additional income sources. The most striking and almost the only source of these is the school- parent association fund. The school-parent association is one of the most important budgetary sources for high schools in which high-school rental income, donations and parental contributions are collected. The budget allocated by the state to the high school and the budget of the school-parent association are used under the supervision of the high school principal. The school-parent association income is one of the main factors of budgetary differences between schools. It can be said that the inequality in the budgets of schools in Turkey results from the other sources than the budget provided by the state.

In order to eliminate the inequality in the budgets of schools, it is important to evaluate the budget resources and expenditures through different variables and to propose models that eliminate inequality. When the literature was studied, there was no study related to this problem and it was determined that there was a gap in this area. Therefore, in this study, it is aimed to determine different relations of income and expense in high school budgets and to present the budget management model proposal to reduce problems and ensure equality. For this purpose, the following questions were attempted to be answered:

- What is the ratio of other income sources except the state budget to total budgets of high schools?

- Does the socio-economic environment of high schools make a difference in budgets other than the state-provided budget?

- Is there any relationship between income and expense of high schools?

- What are the views of the high school members (principal, teacher, student, parent, schoolparent association member) on the ideal school budget model?

\section{Method}

The research, which is designed to propose a budget model to prevent inequalities in education, has been structured on three types of inequalities in educational opportunities; 1-Internal, 2-State, 3Environmental (Underwood, 1994). In this study, it was focused on the inequalities arising from the state and the environment, because the measurement of internal inequalities is impossible and its evaluation can not provide healthy data for the suggestion of the model. In order to evaluate the inequalities arising from the state and the environment and to propose the equality-providing budget model, all the budget inputs to the schools were studied at the high school level. In this context, as the inequalities of schools, especially by the state and the environment, affect the social inequalities, the relationship between the state and environmental supports is evaluated. In this research, the relationship between incomes and expenditures of high school budgets was evaluated, as well as determining the income needed in high school budgets. In the study, the teachers' salary was not included in the budget since they were paid by the Ministry of National Education.

In the study, for socio-economic differences, the definitions of Välijärvi and Malin (2000) on socioeconomic differences were used. The geographical location of the school represents the social structure of that environment. However, another factor of the study, the school's choice of student was not excluded. Anatolian high schools, which are a kind of general high schools in Turkey, are studied within the scope of that study, and since schools choose student or student choose school, it was thought that the variable of social status could be effective. Therefore, the principals from research participants were asked to define the socio-economic environment (1-lower, 2-medium, 3- high) in which their schools were located.In the study, Hanushek's (2013) discussions about the relationship between school budget and student performance were not included since student performance can originate from very different variables (intelligence, age, family education level, socioeconomic environment, social development, etc.) and the measurement of all these variables are not possible as well as the contribution of the similar student performance evaluations (national / international exams) in providing equity is limited. 


\section{Research Design}

In this research, mixed method was used to determine different relations of income and expense in general high school budgets, and to reveal the opinions of school members about budget management model proposals.

\section{Research Instruments and Procedures}

In order to determine the income and expense relations of high school budgets and to reveal the views of principals about the budget management model proposals in the quantitative side of the research, the budget information related to the incomes and expenses of high schools in Turkey and the budget management proposals were collected through "Survey for Views of Anatolian High School Principals About the Budget Management". "Survey for Views of Anatolian High School Principals About the Budget Management" was sent to 20 field experts and 3 expert of assessment and evaluation before they were applied, updated with their opinions and after applying pilot scheme to 2 Anatolian high school principals, it was applied to high school principals who participated in the study. A total of five different semi-structured interview forms were prepared for each member of school (school principal, teacher, student, parent, school-parent association) to obtain their in-depth views on the budget management model proposals for the qualitative side of the research. Prior to the application of the forms, they were sent to 20 field experts and 3 experts of assessment and evaluation, updated with their opinions and after applying pilot scheme to a school principal, a teacher, a student, a parent, and a member of school-parent association, the forms got the finishing touches and were applied.

\section{Participants}

High school principals are important in the management of the budget provided to the general high schools by both state and non-governmental sources. Although some laws (Public Financial Management and Control Law No. 5018, Public Procurement Law No. 4734) provides an understanding of the budget management processes, these laws cover all public institutions and do not include direct articles for budget management in the school. According to the Regulation on Secondary Education of the Ministry of National Education, it is foreseen that the processes related to budget and budget management will be ensured with the cooperation of the school principal, the deputy directors and the school-parent association. In this case, it is very important for high school principals to manage the process in budget management. After the budget is allocated to the school and the allowances are made available, the school principal executes the management process. Official processes related to budget management is monitored via an online database (TEFBIS- Information Management System of Educational Finance and Educations Expenses in Turkey).

There are 2232 principals of the Anatolian high schools in Turkey. Within the scope of the research, the number of sample was determined as 1180 public high school principals for the $2 \%$ acceptable error rate in the calculation using the sample formula of Cochran $(1977,75)$. Through stratified sampling, the associational situations of income and expense data of total $1180 \mathrm{high}$ schools in the representational rate from all cities of Turkey (81 cities). In order to obtain in-depth information about the model proposals, the opinions of 60 school members (school principal, teacher, student, parent, school-parent association member) which were selected by purposive sampling technique were evaluated. Purposeful sampling allows the researcher to select participants who are suitable for the purpose of the research. In this way, people who can answer research questions and have experience related to research questions can be selected. As a sampling type in the study, interviews were conducted with selected school components with different gender ages and experiences from regions with high, medium and low socioeconomic income by using maximum diversity sampling.

\section{Data Analysis}

The quantitative data of the study were gathered reaching participants themselves through a 33item questionnaire and high school principals. In the analysis of the data, statistical techniques such as frequency, percentage, one-way analysis of variance (ANOVA), correlation analysis and regression analysis were used among descriptive statistics in accordance with the problem of research and research questions. In the qualitative side of the study, data were collected face to face by means of interview forms prepared by taking expert opinions. Descriptive and content analysis were used to analyze the 
data. In addition, the relationship matrix was created through the MAXQDA program. As the research covered all Turkey, the legal permission was taken for the field study from the Ministry of National Education. In addition, due to face-to-face data collection from the participants, the permission was received from Ethics Committee in Ankara University.

\section{Results}

This title covers budgetary sources and socio-economic environment, the model of high school's income-expense relationship and the budget types of high schools and model proposals for budgetary participation topics.

\section{Budget Sources and Socioeconomic Environment}

Apart from the budget given by the state, high schools also have different budgetary resources. In the scope of this study, the data related to the ratio of additional budgets to total budget other than the budget given to the high schools by the state has been analyzed using percentage and frequency values. The ratio of additional budget resources of high schools other than that given by the state to the total budget was studied. The ratio of additional budgets other than the budget given by the state to the total budgets of high schools is given in Table 1 .

\section{Table 1}

Ratio of additional budgetary resources to the total budgets of high schools (\%)

\begin{tabular}{lrr}
\hline $\begin{array}{l}\text { Ratio of additional budgetary resources } \\
\text { to the total budget }(\%)\end{array}$ & $\mathbf{n}$ & $\%$ \\
\hline 0 & 100 & 8.5 \\
$1-10$ & 259 & 22.0 \\
$11-20$ & 234 & 19.8 \\
$21-30$ & 158 & 13.4 \\
$31-40$ & 144 & 12.2 \\
$41-50$ & 104 & 8.8 \\
$51-60$ & 79 & 6.7 \\
$61-70$ & 50 & 4.2 \\
$71-80$ & 28 & 2.4 \\
$81-90$ & 18 & 1.5 \\
$91-100$ & 6 & 0.5 \\
Total & $\mathbf{1 1 8 0}$ & $\mathbf{1 0 0}$ \\
\hline
\end{tabular}

As it can be seen in Table 1, 8.5\% of the high schools in the sample maintain their education only through the government budget without any additional income. This means that there is no environmental financial contribution to the high school except for the state contribution. This situation is a quite critical issue. This situation also shows that high schools cannot spend on the quality of education except for the compulsory expenditures. Çınkır's study (2010), called "Problems of Primary School Principals: Sources for Problems and Support Strategies"also supports these findings. This research indicates that the first problem of the school budget among the problems faced by primary school principals in Turkey is related to the problems about the school budget and management of general and administrative services.

Another remarkable point in Table 1 is that a high school group of $2 \%$ (24) gets more than $80 \%$ of their total budgets by external sources. This means that more than $80 \%$ of the income of these high schools is made up of environmental resources; that is, additional budgets other than the budget allocated by the state. In addition to not having any environmental resources, it is clear that inequality will deepen among the high schools that provide almost all of their budget from sources other than the state. 
High school stake additional budgets other than the state-provided budget by different sources such as school-parent associations, parent donations, sponsors. For this reason, the ratio of additional budgetary resources within the total budget is important. The results of one-way analysis ofvariance related to socioeconomic environment relationship and the ratio of additional budget resources of high schools to total budget are given in Table 2.

\section{Table 2}

The results of ANOVA analysis related to the relationship of socioeconomic level and the ratio of additional budgetary resources to total budget of high schools

\begin{tabular}{|c|c|c|c|c|c|}
\hline Socio Economic Level & Sum of Squares & Df & $\begin{array}{l}\text { Meanof } \\
\text { Squares }\end{array}$ & $\mathbf{F}$ & $\mathbf{p}$ \\
\hline between groups & 23162.57 & 2 & 11581.28 & & \\
\hline within groups & 546475.14 & 1177 & 464.29 & 24.94 & $0.00 *$ \\
\hline Total & 569637.70 & 1179 & & & \\
\hline
\end{tabular}

Within the scope of research, one-way analysis of variance (ANOVA) was performed for the comparison of the ratio of non-budgetary financial resources of high schools at lower, middle and high socio economic levels to total budgets. According to the results of one-way analysis of variance, a significant difference was observed between the extra-budgetary financial resources of schools in high socioeconomic level (SEL) $(p<0.05)$. The results of comparisons among groups are shown in Table 3.

Table 3

ANOVA results of multiple comparisons between the ratio of additional budgetary resources to total budgets based on the socio-economic level of high schools

\begin{tabular}{llrc}
\hline $\begin{array}{l}\text { Socio economic } \\
\text { level }\end{array}$ & $\begin{array}{l}\text { Socio economic } \\
\text { level }\end{array}$ & Mean difference & P \\
\hline Lower & Medium & -6.75 & .000 \\
& High & -22.04 & .000 \\
Medium & Lower & 6.75 & .000 \\
& High & -15.29 & .000 \\
High & Lower & 22.04 & .000 \\
& Medium & 15.29 & .000 \\
\hline
\end{tabular}

As it can be seen in Table 3, there is a significant difference among the ratio of the additional budgets to the total budgets of the high schools in lower, medium and high levels. The ratio of additional budgetary resources to total budgets for high schools in high socioeconomic regions is higher than that of the high schools in lower and medium socioeconomic level. The ratio of additional budgetary resources to total budgets of high schools in medium socioeconomic level is higher than that of high schools in lower socioeconomic level. Özdemir's (2011) research also supports these findings. It was concluded that as the socio-economic level of the schools increased, the amount of income obtained by the school-parent associations increased. The presence of schools in the high socio-economic region is related to the parent profile with high level of income.

\section{The Model of Income-Expenditure Relationship of High Schools}

When the quantitative data obtained from the survey were examined, it was observed that for the reasons of the most common problems $63.1 \%$ of the principals of high schools said that they could not some maintenance and repair work of school; $43.7 \%$, that they could not allocate source for poor students; $43.4 \%$ that they could not allocate source for the participation of students in art and sports activities; $37.8 \%$, that they could not improve the library of school physically and for its content; $35 \%$, they could not provide cleaning service; $27 \%$, they could not support the participation of teachers of school in the scientific and professional meetings/trainings; $16.4 \%$, they could not provide source for 
the education of female students; $13.5 \%$, they could not provide material for courses; $8 \%$, they could not pay the bills of electricity, water, natural gas and phone; $1.4 \%$, they could not allocate source for the security of school; $53.6 \%$ said "other". In other answers, they stated that high school principals could not pay salary payments for auxiliary personnel (cleaning, etc.), not pay the debts of the school, not be able to employ sufficient number of auxiliary services personnel, not improve the physical conditions of the school, not make major repairs, not pay the internet bills, and cannot meet their residency requirements.

Based on these responses, multiple regression model applications have been performed in order to examine the expenses and income relations in the most problematic areas and to propose a model for the solution of the problems in this direction. In this study, first of all, multiple linear regression analysis modeling method was used in order to examine to what extent the budget by the state and school-parent association fund predict the expenses, including "movable property, intangible right, maintenance repair expense"; that is the purchase for the maintenance-repair work. This expense was chosen for the analysis since it was the most problematic expense. The results of the multiple regression modeling method are given in Table 4.

\section{Table 4}

The regression analysis results of the expenses of movable property, intangible right and maintenancerepair work and the funds by the state and the school-parent association

\begin{tabular}{llllllll}
\hline Variables & B & $\begin{array}{l}\text { Std } \\
\text { Error }\end{array}$ & B & T & p & Binaryr & Partilar \\
\hline Constant & 14781.634 & 1445.399 & & 10.227 & 0.00 & & \\
\hline $\begin{array}{l}\text { Funds } \\
\text { provided by } \\
\text { the Ministry of }\end{array}$ & 0.58 & 0.008 & 0.234 & 6.862 & 0.00 & 0.234 & 0.236 \\
$\begin{array}{l}\text { National } \\
\text { Education }\end{array}$ & & & & & & & \\
\hline $\begin{array}{l}\text { School-parent } \\
\text { association } \\
\text { incomes }\end{array}$ & 0.124 & 0.035 & 0.120 & 3.518 & 0.00 & 0.120 & 0.123 \\
\hline $\mathrm{R}=.266, \mathrm{R}^{2}=.071, \mathrm{~F}=30.499, p<.001$ & & & & & & \\
\hline
\end{tabular}

When the model is examined, $p<0.05$ is seen. According to this model, there is a significant relationship between expenses of movable property, intangible right and maintenance-repair work and the funds by the state and the school-parent association. It can be said that there is a significant and low level $(R=0.266)$ relationship between the expenses of movable property, intangible right and maintenance-repair work and the funds by the state and the school-parent association. It is seen that there is a significant relationship between the budget provided by the state, the school-parent association, and the expenses of movable property, intangible right and maintenance-repair work, which are two variables. However, this data explains $7 \%$ of the total variance $\left(R^{2}=0.07\right)$. When the coefficients of the binary correlation are examined, it is seen that the state budget $(\mathrm{r}=0.234)$ and the school- parent association funds $(r=0.120)$ have a low and positive relationship. According to the standardized regression coefficients $(\beta)$, the order of relative importance of the independent variables to the dependent variables, the expenses of movable property, intangible right and maintenance-repair work, and the order funds given by the state and school-parent association to the high schools are given. As a result, it was seen that the budget allocated to the school by the government affects the expenses of movable property, intangible right and maintenance-repair work. Therefore, there is a need to increase the budget provided by the state to the school for the need of maintenance-repair work, which has been reported to be problem by the high school principals.

Another important expense within the scope of the research is the service purchases, which include cleaning, security etc. For this reason, in this study, first of all, multiple linear regression analysis modeling method was used in order to determine to what extent the budget by the state and 
school-parent association fund is related to the service purchases. The results of the multiple regression modeling method are given in Table 5.

Table 5

Regression analysis results of the service purchases and funds by the national state and the schoolparent association

\begin{tabular}{llllllll}
\hline Variables & B & Std & B & T & p & Binaryr & Partilar \\
\hline Constant & 37168.5 & 8978.59 & & 4.140 & 0.00 & & \\
$\begin{array}{l}\text { Funds provided by } \\
\text { Ministry of }\end{array}$ & 0.344 & 0.152 & 0.108 & 2.254 & 0.025 & 0.260 & 0.261 \\
$\begin{array}{l}\text { National } \\
\text { Education }\end{array}$ & & & & & & & \\
\hline $\begin{array}{l}\text { School-parent } \\
\text { association } \\
\text { incomes }\end{array}$ & 0.241 & 0.44 & 0.260 & 5.454 & 0.00 & 0.107 & 0.111 \\
\hline $\mathrm{R}=.277, \mathrm{R}^{2}=.077, \mathrm{~F}=16,868, p<.001$ & & & & & & \\
\end{tabular}

When the model is analyzed in Table 5, $p<0.05$ value is seen. According to this model, there is a significant relationship between service purchases and funds by the national state and the schoolparent association. It can be said that there is a meaningful and low level $(R=0,277)$ relationship between the service purchases of high schools and the funds allocated by the state and the schoolparent association funds. It is seen that there is a significant relationship between the service purchases and the funds by the national state and the school-parent association. However, this data explains 7\% of the total variance $\left(\mathrm{R}^{2}=0.07\right)$. When the coefficients of the binary correlation are examined, it is seen that the state budget $(r=0.260)$ and the school-parent association funds $(r=0.107)$ have a low and positive relationship. According to the standardized regression coefficients (B), the relative importance of the independent variables to the service purchase expenditures, which are the dependent variable, is listed as the budget provided by the state to high school budget and school-parent association funds. As a result, it was seen that the funds provided by Ministry of National Education and school-parent association incomes affects service purchases.

\section{Model Proposal for the Budget Type and Budget Participation of High Schools}

On the quantitative side of the study, for the data obtained from 1180 high schools the school principals were asked how to finance the schools. Principals were able to mark more than one option. The answers obtained are shown in Table 6.

\section{Table 6}

Distribution of findings about budget model planned by high school principals

\begin{tabular}{lcc}
\hline Planned Budget Model & n & \% \\
\hline I will plan a model in which schools are independent in creating source and spending. & 319 & 27.0 \\
I will plan a model in which all sources will be provided by Ministry of Education and additional & 676 & 57.3 \\
sources will not be needed. & 170 & 14.4 \\
I will plan a model in which schools manage the budget independently in cooperation with the & & \\
school-parent association. & 436 & 36.9 \\
I will plan a model in which there will be a specific employee who is responsible for the records & 360 & 30.5 \\
of income and expenses in school. & 220 & 18.6 \\
I will plan a model in which all authority belongs to the principal. & 11 & 0.9 \\
I will plan a model in which all components of the school (student, teacher, officials, service & 3 & 0.3 \\
personnel, school-parent association member, parent) have a say in the budget management. & 3 will plan a model in which train specially school principals. & 3
\end{tabular}

As shown in Table 6 , it has been seen that $57.3 \%$ of high school principals will plan a model in which all sources will be provided by the state and additional sources will not be needed; $36.9 \%$, in which there will be a specific employee who is responsible for the records of income and expenses in school; $30.5 \%$, in which all authority belongs to the principal; $27 \%$, in which schools are independent in creating source and spending; $18.6 \%$, in which all members of the school (student, teacher, officials, 
service personnel, school-parent association member, parent) have a say in the budget management; $14.4 \%$, in which schools manage the budget independently in cooperation with the school-parent association. It is also noteworthy that there are the ones $(0.9 \%)$ that emphasize the need to train school principals.

In addition to the high school principals, other school members were asked how they would design a school budget management model on the qualitative side of the research. For the budget management system to be designed by the members of the school, it was seen that they gave the responses of public-provided budgeting, mixed budget, special budget and bag budgeting for the financing of the sources. The answers of school members to whom there should be in decision-making process in the designed model and budget funds are given in Figure 1.

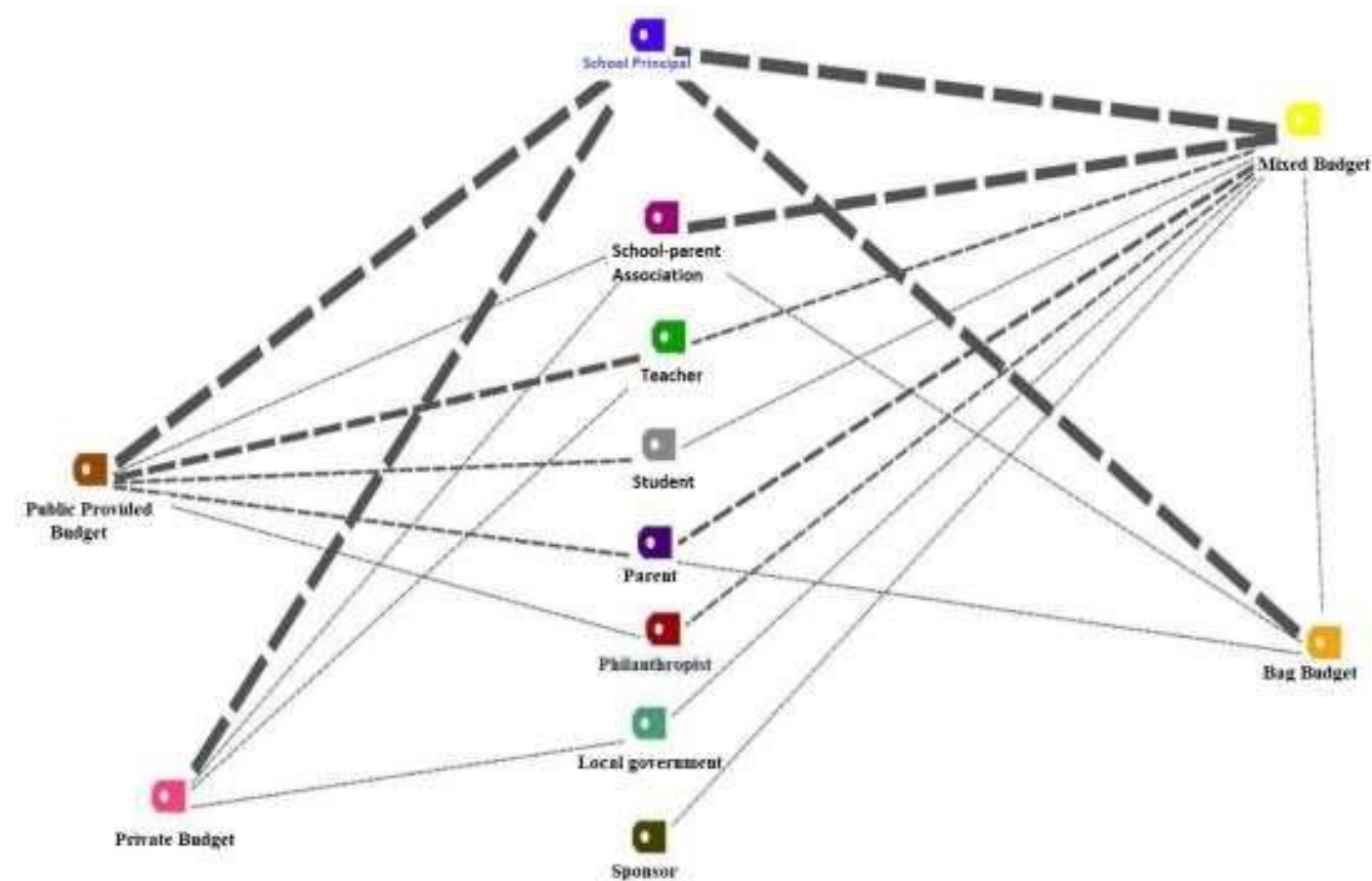

Figure 1. Matrices of school members related to budget management

When the matrix related to the model is examined, it is observed that the most intense relationship between the units is between the principal and the public-provided budget, private budget, mixed budget and bag budgeting. At the same time, there is an intense relationship between the school-parent association and the demand for mixed budget. When the model matrix is examined, it is seen that teachers and students predominantly propose a public-provided budget. It is observed that those who want parents to co-ordinate the system prefer the mixed budget more intensely. It is seen that those whose models include principal choose the public-provided budget, private budget, mixed budget and predominantly bag budgeting.

\section{Conclusion}

The additional budgetary resources of the high schools except the state budget are affected by the socio-economic conditions of the school. If a high school is in a high socioeconomic environment, the budget provided by the state to the high school does not have a large contribution compared to the additional budget. This means that additional budgets can reach such large proportions that additional budgets are more important within the total budget. However, it is difficult to find additional budgetary resources for the schools in the lower socioeconomic environment. The most important budget for these schools is the budget given by the state. For this reason,in order to ensure equality,the socio-economic environments in which schools are located can be mapped and this map can bee valuated in the distribution of the budget. 
There is a low relationship between the income and expenses of high schools. The expenses of movable property, intangible right, maintenance-repair are affected by the budget provided by the state. Therefore, by allocating more budget to the schools by the state, problems in maintenance and repair can be solved. However, considering that public resources are limited, additional budgetary resources can be created to meet the expense items.

It is the ideal system for high schools to have the budget provided by the state and to manage their budget with the participation of different school members. The participation of different school members is important in order to reveal the problems of the system from different angles and to provide the quality of education by spending the budget in order to solve these problems.

\section{References}

Augenblick, J., Myers, J., \& Anderson, A. (1997). Equity and Adequacy in School Funding. The Future of Children, 7 (3), 63-78. doi:10.2307/1602446.

Brighouse, H. (2007). Educational Justice and Socio-Economic Segregation in Schools. Journal of Philosophy of Education, 41(4), 575-590.

Card, D., \& Payne, A. A. (2002). School finance reform, the distribution of school spending, and the distribution of student test scores. Journal of Public Economics, 83(1), 49-82.

Cochran, W. G. (1977). Sampling tecniques, 3rd Edition, Wiley Press.

Çınkır, Ş. (2010). Problems of primary school headteachers: problem sources and support strategies, Elementary Education Online, 9(3), 1027-1036.

Davies, B., \& Hentschke, G. C. (1994). School autonomy: Myth or reality-Developing an analytical taxonomy. Educational Management \& Administration, 22(2), 96-103.

Guthrie, J. (1997). School finance: fifty years of expansion. The Future of Children,7(3), 24-38. doi: $10.2307 / 1602443$.

Hanushek, E. A. (2013), "Financing Schools", in J. Hattie, and E. M. Anderman (Eds.), International guide to student achievement, New York, Routledge.

Hough, J. R. (1993). Financial management in education, Lough Borough University. UK.

Howell, P., \& Miller, B. (1997). Sources of Funding for Schools. The Future of Children, 7 (3), 39-50. doi:10.2307/1602444.

Ikpa, V. W. (2016). Politics, adequacy, and education funding. Education, 136 (4), 468 -472.

Kozol, J. (2005). The shame of the nation: The restoration of apartheid schooling in America. Broadway Books.

Odden, A., (1992). Rethinking school finance: An agenda for the 1990s. San Francisco, CA: JosseyBass, 1992, p. 33.

Odden, A., Goetz, M. E., \& Picus, L. (2007). Paying for school finance adequacy with thenational average expenditure per pupil. School Finance Redesign Project, Center on Reinventing Public Education.

Özdemir, N. (2011). A tool for primary education financing: Analysis of parent teacher association's budget (Example of Ankara). Master thesis, Hacettepe University Institute of Social Sciences, Ankara.

Rubenstein, R., Schwartz, A. E., Stiefel, L., \& Amor, H. B. H. (2007). From districts to schools: The distribution of resources across schools in big city school districts. Economics of Education Review, 26(5), 532-545.

Terman, D., \& Behrman, R. (1997). Financing Schools: Analysis and Recommendations. The Future of Children,7(3), 4-23. doi:10.2307/1602442. 
Underwood, J. K. (1994). School finance adequacy as vertical equity. U. Mich. JL Reform, 28, 493.

Välijärvi,J., \& Malin, A. (2000). 10 The Two-Level Effect of Socio-Economic Background, Ed. Lie, S., Linnakylä, P., \& Roe, A. (2000). Northern lights on PISA, 7, 1. 
